13. Нодель М. Р. Депрессия при болезни Паркинсона // Неврология, нейропсихиатрия, психосоматика. 2010. С. 11-17.

14. Nonmotor Symptoms in Early- and Advanced-Stage Parkinson's Disease Patients on Dopaminergic Therapy: How Do They Correlate with Quality of Life? / Valkovic P. et. al. // ISRN Neurology. 2014. Vol. 2014. doi: 10.1155/2014/587302

15. Gallagher D. A., Lees A. J., Shrag A. What are the most important non-mo-tor symptoms in patients with Parkinsons disease and are we missing them? // Movement Disorders. 2011. Vol. 25, Issue 15. P. 2493-2500. doi: 10.1002/mds.23394

16. Nodel M. R. The impact of neuropsychiatric symptoms on quality of life of patients with parkinson's disease // The Neurological Journal. 2015. Vol. 20, Issue 1. P. 20-25. doi: 10.18821/1560-9545-2015-20-1-20-27

17. Предикторы развития когнитивных и аффективных нарушений при болезни Паркинсона / Ляшенко Е. А. и др. // Земский врач. 2014. № 3-4 (24). С. 9-12.

Рекомендовано до публікації д-р мед. наук, професор Головченко Ю. I. Дата надходження рукопису 05.04.2018

Чеборака Тетяна Олександрівна, аспірант, кафедра неврології № 1, Національна медична академія післядипломної освіти імені П. Л. Шупика, вул. Дорогожицька, 9, м. Київ, Україна, 04112

E-mail: tatyana.neurology@gmail.com

UDC: 616.831.9-002.1-022-008.8-078:57.088.6

DOI: $10.15587 / 2519-4798.2018 .132688$

\title{
BIOCHEMICAL PARAMETERS OF CEREBROSPINAL FLUID IN PATIENTS WITH ACUTE VIRAL MENINGITIS AND MENINGOENCEPHALITIS
}

\author{
(C) V. Kozko, A. Sokhan, Ya. Burma, A. Kuznietsova, A. Gavrylov
}

Мета дослідження. Визначення діагностичної иінності вмісту лактату, лактатдегідрогенази, креатинінкінази, кислої фосфатази та холінестерази у ЦСР для ранньої діагностики та прогнозування перебігу гострого вірусного менінгіту та менінгоенцефаліту.

Матеріали та методи. Було обстежено 92 пацієнта з підтвердженою вірусною етіологією захворювання. Серед них - 20 хворих на ВПГ 1,2 нейроінфекцію, 19 хворих на ЕБВ нейроінфекцію, 15 з ВЗВ нейроінфекцією, 14 - з ВГЛ-6 нейроінфекцією і 24 пацієнта з ентеровірусним менінгітом. Пацієнти були розділені на групи в залежності від етіології та тяжкості хвороби. На додаток до аналізу клінічного перебігу захворювання, ми провели дослідження ЦСР хворих для визначення рівня креатинінкінази, лактаmу, лактатдегідрогенази, креатинінкінази, холінестерази та кислої фосфатази при стаціонарі та через 10-12 днів лікування.

Результати дослідження. Найвищий середній вік спостерігався у пацієнтів з ВЗВ менінгітом - 38,27士

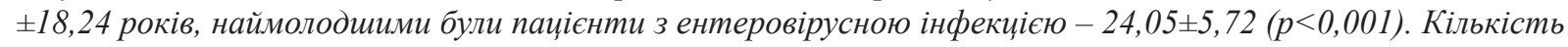
жінок та чоловіків була однаковою практично у всіх групах, проте серед пацієнтів з ВПГ 1,2 нейроінфекиією жінки значно переважали - 16 (80\%) з 20 випадків. Найбільи тяжкий перебіг спостерігався у групах ЕБВ та ВГЛ-6 нейроінфекиій, де тяжккии перебіг спостерігався у 47,37\% та 35, 71 \% паиієнтів відповідно. Нейроінфекиії ентеровірусної етіології мали найбільи сприятливий перебіг.

Отримані дані вказують на залежність рівнів показників, щуо досліджувались перш за все від тяжкості хвороби. Рівень креатинінкінази та кислотної фосфатази у пацієнтів з середньою тяжкістю був значно вищим порівняно з тяжкими пацієнтами $(p<0,05)$. Рівень лактату був вищим у хворих з тяжкою нейроінфекиісю $(p<0,05)$. Найвищі рівні лактату визначались у хворих з ВГЛ-6 менінгоенцефалітом $(p<0,05)$. Рівень холінестерази був достеменно нижчим у тяжких хворих.

Висновки. Отримані результати підтверджують наявність глибоких метаболічних порушень у тканинах головного мозку у всіх хворих на гострі вірусні нейроінфекиії як на початку хвороби так і в динаміці лікування. Визначення рівнів креатинінкінази, кислої фосфатази, лактату та холінестерази у ЦСР хворих на гострі вірусні нейроінфекції має високу діагностичну ичінність, однак не можуть бути використані для прогнозу несприятливого перебігу хвороби

Ключові слова: иеереброспінальна рідина, менінгіт, менінгоенщефаліт, кисла фосфатаза, креатинінкіназа, лактат, лактатдегідрогеназа, холінестераза

\section{Introduction}

Neuroinfection is a worldwide problem, an important cause of morbidity and mortality in the world and in Ukraine [1,2]. Viral infections are the main cause of meningitis and meningoencephalitis worldwide. They exceed the frequency of bacterial, fungal and protozoan neuroinfections [1]. At present believed that the etiology of viral defeat of the central nervous system (CNS) is 
most often due to enteroviruses, herpes viruses and some arboviruses. At the same time, $39 \%$ of infections caused by these viruses lead to serious neurological disorders [1]. Herpesvirus neuroinfections are the most severe among the all viral lesion of the CNS, most often cause neurological disorders and have the highest mortality [2]. In connection with the morphological and functional features of the CNS, the diagnostics of meningitis and meningoencephalitis remains imperfect. At the present stage, only clinical and anamnestic indices, indicators of clinical analysis of cerebrospinal fluid (CSF) and, if there is such a possibility, data of magnetic resonance or computer tomography are used during work with patients with neuroinfection.

\section{Case presentation}

Viral infections of the CNS encompass both acute and chronic conditions caused by broad range of different pathogens. As a group, these diseases can have a complex and variable pathogenesis that is influenced by host, viral, and environmental factors [3]. Virus infection of the brain can cause severe and life-threatening disease [4]. The results of routine procedures to evaluate the CSF, e. g. pleocytosis and cytogram, protein, glucose and chloride concentrations seem not always to reflect the actual intensity of the inflammatory process in the cerebral tissue in such conditions. As a result of viral damage to the meninges and brain tissues, the permeability of the blood-brain barrier (BBB) is disrupted and metabolic disorders such as hypoxia, acidosis, oxidative stress develop. Such multifactorial disorders lead to cerebral edema, necrosis and apoptosis of brain cells [5]. Since prompt and precise etiological diagnosis remains a challenge and often a thorough cerebrospinal fluid examination may not give a precise diagnosis, a quick and reliable test is required for rapid bedside diagnosis. Many enzymes are known to be present in abundance in the nervous system. Meningitis disturbs the BBB and is expected to cause rise in enzymatic activity. Therefore, various investigators have used them for the diagnosis as well as for determining the prognosis in cases of meningitis [6]. However, the role of various CSF enzymes needs to be evaluated as not enough work has been carried out and majority of workers have estimated one of these enzymes either in CSF or serum. Furthermore, several advanced CSF parameters, such as CSF lactate, lactate dehydrogenase (LDG), creatinine kinase (CK), acid phosphatase (ACP) and cholinesterase (CHE), were not evaluated in series of patients with virus meningoencephalitis in contrast to bacterial CNS infections where the beneficial contribution of the CSF has been established.

In this regard, studies aimed at determining the criteria for assessing the severity of the metabolic disorders, forecasting and monitoring the effectiveness of treatment in a particular patient are becoming especially relevant. It may increase the effectiveness of treatment and reduces the severity of residual effects.

\section{Purpose}

The purpose of the study was to evaluate the diagnostic value of lactate, lactate dehydrogenase, creatinine kinase, acid phosphatase, and cholinesterase in the CSF for early diagnostics and prognostication of acute viral meningitis and meningoencephalitis.

\section{Materials and methods}

For the purpose of the study, a comprehensive examination of 453 patients with acute neuroinfection who were treated during 2010-2017 at the Regional Clinical Infectious Diseases Hospital (Kharkiv, Ukraine) was carried out. The study was approved by the local Bioethics Committee of the National Medical University (Kharkiv, Ukraine). Inclusion of patients in the study was carried out in accordance with the selection criteria. Inclusion criteria: clinical symptoms typical for acute meningitis, etiological confirmation of the viral etiology of the disease, age of patients from 18 to 70 years, voluntary consent of the patient to participate in the study. In patients with violations of consciousness or cognitive function during admission to a hospital, voluntary consent to participate in the study was obtained after the normalization of the higher nervous activity function. Patients were excluded in the following cases: presence of diseases of the pituitary-adrenal system in history, HIV infection, neoplasms. The average age of the patients was $33.54 \pm 2,76$ years.

Etiology of neuroinfection was determined by PCR method of CSF. CSF was obtained by lumbar puncture. The execution of lumbar puncture was performed in accordance with the local protocols of Regional Clinical Infectious Diseases Hospital and in accordance with the standards of medical care for patients with acute meningitis and herpes virus neuroinfections of the Ministry of Health of Ukraine, № 487, 17.08.2007 About the approval of clinical protocols for the provision of medical care in the specialty "Neurology". Patients who participated in the study were not subjected to additional invasive procedures.

We selected 92 patients with confirmed viral etiology of the disease. Among them - 20 patients with herpes simplex virus 1,2 types (HSV 1,2) infection, 19 with Epstein Barr (EBV) infection, 15 with varicella zoster infection (VZV), 14 with human herpesvirus type $6(\mathrm{HHV}-6)$ and 24 patients with enterovirus meningitis. The patients were divided into groups depending on the etiology of neuroinfection. We also divided patients into subgroups of meningitis and meningoencephalitis.

In addition to analyzing the clinical course of the disease, we performed the studies of patients CSF to determine the levels of CK, lactate, LDG, CK, CHE and ACP when inpatient and 10-12 days after treatment.

The levels of CK, LDG, CK, CHE and ACP were determined by the kinetic-photometric method using the diagnostic of the company "DAC-SpectroMed" (Moldova); the level of lactate was determined by the enzymatic calorimetric method using a set of Olvex Diagnosticum (Russian Federation). The research was carried out in the Central Scientific Research Laboratory of the Kharkiv National Medical University.

The results are statistically processed using the 6th version of BiostatPro, AnalystSoft Inc. The verification 
of the normality of the distribution of indicators in the samples was carried out using the Kolmogorov-Smirnov criterion. According to the size of the sample and the distribution of values, methods of non-parametric statistics were used (Mann-Whitney's U-test). Indicators are given as Me $(25,75 \%)$ (Median (25; 75 percentile)), and absolute value (percent) (n \%). The difference was considered probable at values $\mathrm{p}<0.05$.

\section{Results}

The average age of patients with enterovirus meningitis was significantly lower than in groups with herpesvirus neuroinfections $(p<0.01)$. The highest age was observed in patients with VZV meningitis - 38.27 \pm 18.24 years, the youngest - in patients with enterovirus meningitis $-24.05 \pm 5.72(\mathrm{p}<0.001)$ (Mann-Whitney's Utest). The quantity of women and men was the same almost in all groups, however, among patients with HSV 1,2 neuroinfection, women significantly predominated $16(80 \%)$ of 20 cases. The most severe was EBV and HHV-6 neuroinfection, a severe course of the disease was observed in $47.37 \%$ and $35.71 \%$ of patients (Table 1 ).

In all patients' severity of the condition was caused by development of focal neurological symptoms and brain edema symptoms. In patients with EBV and HHV-6 neuroinfection, symptoms of focal lesions of the brain in the form of paresis, paralysis and cognitive impairment were more common.

The disease of moderate severity was observed in 15 (75 \%) with HSV 1,2, 10 (52.63\%) with EBV, 11 (73.33 \%) with VZV, 9 (64.29 \%) with HHV-6 and 24 (100\%) with enterovirus etiology of the disease. The highest mortality was observed in patients with EBV (10.53 \%) and HHV-6 $(7.14 \%)$ neuroinfection (Table 1$)$.

The levels of CK, lactate, LDG, CK, CHE and ACP in the CSF of patients with medium severity course of virus neuroinfection on the first day of treatment are summarized in Table 2, in patients with severe course of disease - in Table 3.

In patients with viral meningitis in the dynamics of the disease their dependence on both the severity of the patient's condition and the etiology of the disease was established in the study of CSF.

The levels of creatinine kinases, lactate, lactate dehydrogenase, cholinesterase and acid phosphatase in the CSF of patients with virus meningitis on the 10 12 day of treatment are summarized in Table 4, in patients with meningoencephalitis - in Table 5.

Table 1

General characteristics of patients depending on the etiology of the disease

\begin{tabular}{|l|c|c|c|c|c|}
\hline Etiology of neuroinfection & HSV 1,2 $(\mathrm{n}=20)$ & EBV $(\mathrm{n}=19)$ & VZV $(\mathrm{n}=15)$ & HHV-6 $(\mathrm{n}=14)$ & Enterovirus $(\mathrm{n}=24)$ \\
\hline $\begin{array}{l}\text { Age of patients } \\
(\text { Mean } \pm \text { SD) }\end{array}$ & $35.5 \pm 14.7$ & $36.4 \pm 16.1$ & $38.3 \pm 18.2$ & $31.7 \pm 13.0$ & $24.1 \pm 5.7$ \\
\hline Men, $\mathrm{n} / \%$ & $4 / 20.0$ & $7 / 36.8$ & $9 / 60.0$ & $8 / 57.1$ & $13 / 54.2$ \\
\hline Women, $\mathrm{n} / \%$ & $16 / 80.0$ & $12 / 63.2$ & $6 / 40.0$ & $6 / 42.9$ & $11 / 45.8$ \\
\hline Meningitis, $\mathrm{n} / \%$ & $15 / 75.0$ & $10 / 52.6$ & $11 / 73.3$ & $9 / 64.3$ & $24 / 10$ \\
\hline Meningoencephalitis, $\mathrm{n} / \%$ & $5 / 25.0$ & $9 / 47.4$ & $4 / 26.7$ & $5 / 35.7$ & $0 /$ \\
\hline Lethal outcome, $\mathrm{n} / \%$ & $1 / 5.0$ & $2 / 10.5$ & $1 / 6.7$ & $1 / 7.1$ & $0 /$ \\
\hline
\end{tabular}

Table 2

Level of CK, lactate, LDG, CK, CHE and ACP in CSF of patients with moderate severity on the first day of treatment, $\mathrm{Me}(\mathrm{Q} 25: \mathrm{Q} 75)$

\begin{tabular}{|l|c|c|c|c|c|}
\hline \multicolumn{1}{|c|}{ Etiology } & CK, (U/l) & ACP, $(\mathrm{U} / \mathrm{l})$ & Lactate, $(\mathrm{mmol} / \mathrm{l})$ & LDG, (U/l) & CHE, (U/1) \\
\hline HSV $(\mathrm{n}=15)$ & $3.64(1.97: 4.05)$ & $0.73(0.67: 0.96)$ & $2.05(1.76: 2.43)$ & $28.04(26.10: 30.54)$ & $187.57(143.64: 201.42)$ \\
\hline EBV $(\mathrm{n}=10)$ & $5.15(2.78: 6.89)$ & $0.92(0.83: 1.31)$ & $1.41(1.05: 1.76)$ & $20.36(14.46: 25.54)$ & $104.68(93.32: 131.05)$ \\
\hline VZV $(\mathrm{n}=11)$ & $3.24(3.04: 3.67)$ & $0.76(0.52: 1.04)$ & $1.91(1.52: 2.52)$ & $23.65(18.22: 31.45)$ & $138.47(110.14: 198.35)$ \\
\hline HHV-6 $(\mathrm{n}=9)$ & $4.52(3.82: 5.17)$ & $0.78(0.74: 0.85)$ & $3.09(2.71: 3.50)$ & $24.90(21.98: 30.05)$ & $168.57(139.86: 204.12)$ \\
\hline Enterovirus $(\mathrm{n}=24)$ & $3.55(1.46: 4.25)$ & $0.59(0.45: 0.76)$ & $1.17(1.08: 1.72)$ & $13.08(11.83: 16.32)$ & $82.74(79.53: 86.59)$ \\
\hline
\end{tabular}

Table 3

Level of CK, ACP, lactate, LDG, CHE in CSF of patients with severe course on the first day of treatment, Me (Q25: Q75)

\begin{tabular}{|l|c|c|c|c|c|}
\hline \multicolumn{1}{|c|}{ Etiology } & CK, $(\mathrm{U} / \mathrm{l})$ & ACP, $(\mathrm{U} / \mathrm{l})$ & Lactate, $(\mathrm{mmol} / \mathrm{l})$ & LDG, $(\mathrm{U} / \mathrm{l})$ & CHE, $(\mathrm{U} / \mathrm{l})$ \\
\hline HSV $(\mathrm{n}=5)$ & $1.05(0.98: 1.32)$ & $0.30(0.21: 0.47)$ & $2.76(2.25: 2.89)$ & $30.56(28.47: 31.74)$ & $254.52(204.31: 276.65)$ \\
\hline EBV $(\mathrm{n}=9)$ & $2.64(1.78: 4.86)$ & $0.38(0.23: 0.49)$ & $3.03(2.67: 3.89)$ & $22.66(14.65: 27.92)$ & $121.87(111.12: 124.76)$ \\
\hline HHV-6 $(\mathrm{n}=5)$ & $4.17(4.05: 6.48)$ & $0.75(0.65: 0.79)$ & $3.83(3.42: 4.29)$ & $19.54(16.84: 20.69)$ & $122.63(121.64: 127.07)$ \\
\hline
\end{tabular}


Table 4

Level of CK, ACP, lactate, LDG, CHE in CSF in patients with moderate severity for 10-12 days of treatment, Me (Q25: Q75)

\begin{tabular}{|l|c|c|c|c|c|}
\hline \multicolumn{1}{|c|}{ Etiology } & CK, $(\mathrm{U} / \mathrm{l})$ & ACP, $(\mathrm{U} / \mathrm{l})$ & Lactate, $(\mathrm{mmol} / \mathrm{l})$ & LDG, $(\mathrm{U} / \mathrm{l})$ & CHE, $(\mathrm{U} / \mathrm{l})$ \\
\hline HSV $(\mathrm{n}=15)$ & $2.05(1.68: 3.01)$ & $0.75(0.33: 0.84)$ & $1.33(0.98: 1.67)$ & $18.46(14.46: 20.74)$ & $112.52(98.42: 132.63)$ \\
\hline EBV $(\mathrm{n}=10)$ & $3.48(2.42: 4.65)$ & $0.63(0.53: 0.94)$ & $1.04(0.87: 1.25)$ & $20.55(17.92: 27.08)$ & $159.62(107.19: 183.81)$ \\
\hline VZV $(\mathrm{n}=11)$ & $1.76(1.54: 2.52)$ & $0.59(0.45: 0.83)$ & $1.14(0.95: 1.77)$ & $13.52(12.86: 20.12)$ & $143.47(86.35: 204.14)$ \\
\hline HHV-6 $(\mathrm{n}=9)$ & $1.37(1.02: 2.02)$ & $0.79(0.75: 0.82)$ & $0.99(0.71: 1.35)$ & $14.34(11.73: 16.61)$ & $166.49(104.50: 194.64)$ \\
\hline Enterovirus $(\mathrm{n}=24)$ & $4.75(3.16: 5.02)$ & $0.60(0.55: 0.83)$ & $1.17(0.95: 1.22)$ & $13.54(10.06: 18.75)$ & $77.26(73.15: 80.94)$ \\
\hline
\end{tabular}

Table 5

Level of CK, ACP, lactate, LDG, CHE in CSF of patients with severe course on 12 days of treatment, Me (Q25: Q75)

\begin{tabular}{|l|c|c|c|c|c|}
\hline \multicolumn{1}{|c|}{ Etiology } & CK, (U/l) & ACP, (U/l) & Lactate, $(\mathrm{mmol} / \mathrm{l})$ & LDG, (U/l) & CHE, (U/l) \\
\hline HSV $(\mathrm{n}=5)$ & $1.25(0.98: 1.67)$ & $0.64(0.48: 0.76)$ & $1.56(0.95: 1.67)$ & $19.47(18.74: 19.57)$ & $143.86(123.53: 156.36)$ \\
\hline EBV $(\mathrm{n}=9)$ & $1.45(1.08: 2.82)$ & $0.71(0.53: 0.79)$ & $1.54(1.37: 2.20)$ & $25.24(19.07: 30.33)$ & $115.87(101.39: 119.41)$ \\
\hline HHV-6 $(\mathrm{n}=5)$ & $4.09(2.17: 6.35)$ & $0.31(0.29: 0.87)$ & $1.32(0.94: 1.41)$ & $16.36(11.53: 20.53)$ & $99.41(95.55: 115.52)$ \\
\hline
\end{tabular}

In the dynamics of the disease, at 10-12 days of treatment and improvement of the patients, decreased levels of CK $(p<0.05)$, increase in cholinesterase activity in severe patients to indicators of moderate severity $(p<0.001)$, decrease in lactate level, which in meningoencephalitis all one remained significantly higher than meningitis $(\mathrm{p}<0.05)$, decreased of lactate dehydrogenase activity $(p<0.05)$ were observed. The level of cholinesterase had a multi-directional pattern in patients with HSV, it decreased $(\mathrm{p}<0.001)$, while in other groups it increased or remained without significant changes.

\section{Discussion}

The level of creatinine kinase and acid phosphatase in patients with moderate severity was significantly higher in comparison with severe patients $(p<0.05)$. Lower activity of creatinine kinase in patients with meningoencephalitis in comparison with meningitis is unexpected, given that in bacterial neuroinfections, the activity of total creatinine kinase increases directly proportional to the severity of the disease [7].

The level of lactate was higher in patients with severe neuroinfection $(p<0.05)$. The level of lactate in CSF reflects the degree of hypoxic-ischemic disorders of the brain tissues. For viral neuroinfections, changes in lactate levels are negligible and almost never reaches values above $3 \mathrm{mmol} / \mathrm{l}$ [8], however, these investigations did not examine patients with HHV-6 infection. Our results indicate that in patients with HHV-6 neuroinfection, the level of lactate is significantly higher in comparison with other viral neuroinfections $(\mathrm{p}<0.001)$ (Table 2, 3). At the same time, lactate dehydrogenase levels did not have differences depending on severity, but were significantly higher in individuals with HSV neuroinfection compared to all other groups of viral meningitis $(\mathrm{p}<0.05)$.

Lowest cholinesterase levels were observed in patients with enteroviral meningitis $(p<0.001)$. In groups with EBV, VZV, HHV-6 neuroinfection, the level of cholinesterase was significantly lower than with HSV-neuroinfection. It also significantly decreased in patients with severe EBV and HHV-6, while in patients with severe course of HSV significant increase of cholinesterase was observed in compared to patients with moderate severity $(\mathrm{p}<0.05)$ (Table 2,3$)$. Cholinesterase is involved in the transmission of nerve impulses. It is supposed that cholinesterase hydrolyzes acetylcholine in the neuromuscular compounds and thus protects them from acetylcholine excess [9, 10]. In addition, cholinesterase is able to hydrolyze many toxic organophosphorus substances. It has been established that the introduction into the animal's blood of serum cholinesterase of a horse or recombinant human cholinesterase protects them from lethal doses of organophosphorus compounds by $100 \%$ [10]. It is assumed that it controls the permeability of cell membranes and vessel walls. There is high probability of enzyme involvement in the formation of neuropeptides, since in the cholinesterase molecule not only the esterase, but also the peptidase active center is localized $[9,10]$.

Thus, an increase of cholinesterase activity in the acute period of neuroinfection, rather, is a sanogenetic reaction to the emerging pathological processes. The low activity of cholinesterase in patients with meningoencephalitis reflects a breakdown of adaptation and possibly leads to the accumulation of toxins and acetylcholine in the tissues of the CNS, which contributes to the development of disorders of nerve impulses transmission, brain edema, and necrotic changes in the CNS.

The presence of metabolic changes in CSF in patients on the 10-12 days of treatment indicates about presence of pathological process in brain tissues longer than the clinical symptoms of the disease. Such results also reflect the differences in the pathogenesis of neuroinfection caused by different viruses and the different efficacy of their therapy. 


\section{Conclusions}

1. The obtained results indicate about presence of statistically significant difference in levels of $\mathrm{CK}, \mathrm{ACP}$, lactate, LDG and CHE in CSF in patients with acute viral neuroinfections in the acute period of the disease.

2. These parameters can be taken into diagnostics and research of viral neuroinfections pathogenesis.

3. Assessment of biochemical parameters of CSF can be used in assessing of the disease severity and effectiveness of the treatment.

4. The indicators of creatinine kinase, lactate and cholinesterase have the greatest diagnostic value on the first day of treatment of patients.

5. Neuroinfections of enterovirus etiology are characterized by the least severe course of the disease.
In the group of enterovirus neuroinfections, the least pronounced changes in biochemical parameters in CSF were revealed.

6. The development of meningoencephalitis is accompanied by deeper changes in biochemical parameters, which reflects the failure of the adaptation of compensatory and adaptive responses and can be used in the diagnosis and treatment of patients.

7. The presence of metabolic changes in CSF in patients with HSV, EBV, and HHV-6 infection on 10-12 days of treatment indicates the presence of a pathological process in brain tissues longer than observed clinical symptoms of the disease and reflects the difference in the pathogenesis and the effectiveness of treatment of various viral neuroinfections.

\section{References}

1. Review of the etiologies of viral meningitis and encephalitis in a dengue endemic region / Soares C. N. et. al. // Journal of the Neurological Sciences. 2011. Vol. 303, Issue 1-2. P. 75-79. doi: 10.1016/j.jns.2011.01.012

2. Lee B. E., Davies H. D. Aseptic meningitis // Current Opinion in Infectious Diseases. 2007. Vol. 20, Issue 3. P. $272-277$. doi: 10.1097/qco.0b013e3280ad4672

3. Irani D. N. Aseptic Meningitis and Viral Myelitis // Neurologic Clinics. 2008. Vol. 26, Issue 3. P. 635-655. doi: 10.1016/ j.ncl.2008.03.003

4. Domingues R. Treatment of Viral Encephalitis // Central Nervous System Agents in Medicinal Chemistry. 2009. Vol. 9, Issue 1. P. 56-62. doi: 10.2174/187152409787601905

5. Silva M. T. T. Viral encephalitis // Arquivos de Neuro-Psiquiatria. 2013. Vol. 71, Issue 9. P. 703-709. doi: 10.1590/0004$282 \times 20130155$

6. Dash P. C., Patro D. Role of CSF CK, LDH, GGTP Enzyme Levels in Diagnostic and Prognostic Evaluation of Meningitis // Journal of Clinical and Diagnostic Research. 2014. Vol. 8, Issue 7. P. 19-22. doi: 10.7860/jcdr/2014/9675.4615

7. Biokhimicheskie pokazateli tserebrospinal'noy zhidkosti bol'nykh ostrymi meningokokkovymi i enterovirusnymi meningitami / Koz'ko V. N. et. al. // Mezhdunarodnyi meditsinskiy zhurnal. 2015. Issue 3. P. 70-74.

8. Cerebrospinal fluid lactate concentration to distinguish bacterial from aseptic meningitis: a systemic review and meta-analysis / Huy N. T. et. al. // Critical Care. 2010. Vol. 14, Issue 6. P. 240. doi: 10.1186/cc9395

9. Stoichiometric and catalytic scavengers as protection against nerve agent toxicity: A mini review / Lenz D. E. et. al. // Toxicology. 2007. Vol. 233, Issue 1-3. P. 31-39. doi: 10.1016/j.tox.2006.11.066

10. Girard E. Butyrylcholinesterase and the control of synaptic responses in acetylcholinesterase knockout mice // Life Sciences. 2007. Vol. 80, Issue 24-25. P. 2380-2385. doi: 10.1016/j.1fs.2007.03.011

Дата надходження рукопису 03.04.2018

Volodymyr Kozko, MD, Professor, Head of Department, Department of Infectious Diseases, Kharkiv National Medical University, Nauky ave., 4, Kharkiv, Ukraine, 61022

E-mail:kozko@ukr.net

Anton Sokhan, PhD, Associate Professor, Department of Infectious Diseases, Kharkiv National Medical University, Nauky ave., 4, Kharkiv, Ukraine, 61022

E-mail: antonsokhan@gmail.com

Yaroslava Burma, PhD, Assistant, Department of Infectious Diseases, Kharkiv National Medical University, Nauky ave., 4, Kharkiv, Ukraine, 61022

E-mail: infectology@ukr.net

Anastasiia Kuznietsova, Assistant, Department of Infectious Diseases, Kharkiv National Medical University, Nauky ave., 4, Kharkiv, Ukraine, 61022

E-mail: nastioshka30@yahoo.com

Anatoliy Gavrylov, PhD, Assistant, Department of Infectious Diseases, Kharkiv National Medical University, Nauky ave., 4, Kharkiv, Ukraine, 61022

E-mail: gaan@ukr.net 